\title{
New Market Power Models and Sex Differences in Pay
}

\author{
Michael R Ransom, Brigham Young University and \\ Institute for the Study of Labor (IZA)
}

\begin{abstract}
Ronald L. Oaxaca, University of Arizona and Institute for the Study of Labor (IZA)
\end{abstract}

In the context of certain models, it is possible to infer the elasticity of labor supply to the firm from the elasticity of the quit rate with respect to the wage. We use this strategy to estimate the elasticity of labor supply for men and women workers at a chain of grocery stores, identifying separation elasticities from differences in wages and separation rates across different job titles within the firm. We estimate that women have lower elasticities, so a Robinson-style monopsony model can explain reasonably well the lower relative pay of women in the retail grocery industry.

\section{Introduction}

In one of the earliest explanations of the "gender gap" in wages, Joan Robinson $(1969,224-27)$ showed that if an employer is a monopsonist

We acknowledge helpful comments on this paper by William Boal, Larry Kahn, Alan Manning, and other participants at the conference "Monopsony in the Labor Market," held in October 2008 at Sundance Resort, UT. We also are grateful for comments on earlier versions of the paper by Dan Hamermesh and Alois Stutzer; from participants at the IZA workshop "The Nature of Discrimination," the Zentrum für Europäische Wirtschaftsforschung workshop "Gender and the Labor Market," the University of California, Merced, conference "Causes and Consequences of Increasing Earnings Inequality," and seminar participants at the University of York, Group d'Analyse et de Théorie Economique, University of Lyon,

[Journal of Labor Economics, 2010, vol. 28, no. 2]

(C) 2010 by The University of Chicago. All rights reserved. 0734-306X/2010/2802-0004\$10.00 
and the elasticities of labor supply of equally productive men and women differ, it is profitable for employers to engage in wage discrimination, paying higher wages to the group with the higher elasticity of supply. Although Robinson's model appears in many economics textbooks, the discussion of it is usually skeptical since it is based on the assumption of a pure monopsony-a single employer of labor in a market-and this seems at odds with the marketplace that we observe almost everywhere. Perhaps for this reason, models of monopsony have not been very influential in the economics literature on labor market discrimination in the past 40 years. ${ }^{1}$ Following Becker (1971), much of this literature has focused primarily on explaining how discriminatory wage differences could occur in competitive markets.

However, some recent models suggest that employers may have market power, even when there are numerous employers in the market. Of course, this is not an entirely new idea. In an early edition of his principles textbook, Samuelson $(1958,559)$ noted the following about the wage policies of companies:

In a perfectly competitive market, a firm need not make decisions on its pay schedules; instead it would turn to the morning newspaper to learn what its wage policy would have to be. Any firm, by raising wages ever so little, could get all the extra help it wanted. If, on the other hand, it cut the wage ever so little, it would find no labor to hire at all in a perfectly competitive labor market.

$\ldots$ The world . . is a blend of (1) competition, and (2) some degree of monopoly power over the wage to be paid. If you try to set your wage too low, you will soon learn this. At first nothing much need happen; but eventually you will find your workers quitting a little more rapidly than would otherwise be the case. Recruitment of new people of the same quality will get harder and harder.

One interpretation of the ideas expressed in these paragraphs has been formalized cleverly in general equilibrium search models of the kind proposed by Burdett and Mortensen (1998). In these types of models, individual firms, although "small" with respect to the labor market, face labor supply curves that slope upward in exactly the way that Samuelson described. The implications of this model for labor market monopsony have been explored in a recent book by Manning (2003). Boal and Ransom (1997) refer to these and related models as "dynamic monopsony" because

and the University of California, Riverside. We received helpful research assistance from Eric Lewis. IZA generously hosted us during June 2005 while we worked on this article. Contact the corresponding author, Michael R Ransom, at ransom@byu.edu.

${ }^{1}$ We do not mean to suggest that contributions such as those of Madden (1973) and Schlicht (1982) are unimportant, but few of the huge volume of papers on discrimination have considered the monopsony model. 
they stress the dynamic nature of the labor market. Essentially, the models formally show how labor market frictions can have an important impact on the operation of the market.

An implication of these models is that the labor supply curve to the firm is related to its wage elasticity of separations. In this article, we use this relationship as a framework within which to estimate the labor supply curve to an individual firm (a retail grocer), taking advantage of the differences in wages and separation rates across different job titles. We find that the elasticity of labor supply to the firm does differ between men and women employees and that this difference is consistent with profitmaximizing discrimination against women workers. While the observed gender wage gap among workers in the retail grocery industry in the United States and in the regional labor market for our firm is fairly consistent with the elasticities that we estimate, we suggest that the observed gap should be smaller if labor market monopsony is the only source of wage differences since there are many institutions in place that limit how such potential market power might be exercised.

\section{Dynamic Monopsony}

Consider a simple dynamic model of monopsony. ${ }^{2}$ The firm's employment in the current period depends on employment during the preceding period and the wage offered in the following way:

$$
N_{t}=\left[1-s\left(w_{t}\right)\right] N_{t-1}+R\left(w_{t}\right),
$$

where $s(w)$ is the separation rate and $R(w)$ is the number of recruits the firm attracts each period with an offer of wage $w_{t}$. In a long-run equilibrium, the size of the firm is constant, so total separations must equal total recruits. Thus,

$$
s(w) N(w)=R(w)
$$

or

$$
N(w)=\frac{R(w)}{s(w)} .
$$

In elasticity form, this relationship can be written as

$$
\varepsilon_{N w}=\varepsilon_{R w}-\varepsilon_{s w} .
$$

It is our intention to estimate a model of labor supply to the firm using this dynamic relationship. However, the employer that we study is clearly not a classic monopsonist but interacts with many employers in a large labor market. At least two recent theoretical approaches to modeling the

${ }^{2}$ In the following discussion, we closely follow parts of the presentation of Manning (2003, chap. 2). 
labor market describe ways by which "small" employers may wield monopsony power. Bhaskar and To (1999) develop a model of monopsonistic competition. In their model, heterogeneous workers have preferences across nonwage characteristics of jobs, such as the geographical location of the job, giving each employer some market power. Another approach is the general equilibrium search model of Burdett and Mortensen (1998), where market power accrues to employers because of search frictions.

In the Burdett-Mortensen model, currently employed workers constantly search for jobs. ${ }^{3}$ As job offers arrive, an employee leaves his current employer if offered a higher wage. If an employer were to increase the offered wage, the rate at which employees leave would fall and recruiting success would increase, leading to a larger workforce. In equilibrium, the flow of recruits to the firm just balances the flow of those who leave, and this defines the labor supply to the firm in exactly the way described by equations (1) and (2) above.

The Burdett-Mortensen model provides two important results for our purposes. First, it gives a consistent theoretical framework that supports the idea that a firm may have power to set wages in the labor market, even in markets with many employers. The second result greatly simplifies our approach to estimating the labor supply to the firm. In their model, firms recruit employees from other employers whose wages are lower. So the recruit of one employer is the separation of another. Thus, the recruitment elasticity is simply the negative of the separation elasticity. (See Manning $[2003,97]$ for a formal derivation of the result.) Therefore, the elasticity of labor supply to the firm can be written as

$$
\varepsilon_{N w}=\varepsilon_{R w}-\varepsilon_{s w}=-2 \varepsilon_{s w} .
$$

This makes it possible to estimate the firm's labor supply elasticity only from information on the firm's separations, a much cleaner problem than estimating the elasticity of recruits with respect to the wage. (Ideally, we would like to estimate the elasticity of the quit rate with respect to the wage rather than the separation rate. However, the data that we use do not distinguish the reason for the separation.)

Clearly, the Burdett-Mortensen model is very abstract and fails to describe many important facts of the labor market. Still, generalizations such as Bontemps, Robin, and Van den Berg (1999) or Mortensen (2003) maintain much of the monopsonistic flavor of the original while providing more useful explanations of labor market phenomena. Nevertheless, some

${ }^{3}$ Unemployed workers also search for jobs, but in the simplest versions of their model, an unemployed worker accepts any job that is offered, regardless of the wage. Since both separation to and hires from unemployment are inelastic with respect to the wage, the only sources of elasticity of the firm's labor supply are job-to-job moves. 
have argued that it is inappropriate to adopt this as a description of the labor market. For example, Kuhn (2004) offers several thoughtful criticisms.

In our work we estimate the elasticity of labor supply to the firm simply by estimating the elasticity of the separation rate with respect to the wage, as in equation (3). The Burdett-Mortensen model provides a formal justification for the approach. However, while the Burdett-Mortensen model is sufficient, it is not strictly necessary. Our empirical approach really depends on only two results: first, that the dynamic labor supply to the firm may be upward sloping and, second, that the separation elasticity is the negative of the recruitment elasticity. The duopsony model presented in Bhaskar, Manning, and To (2002), for example, is basically consistent with this approach. The second, however, depends on the notion that one firm's separations are the recruits of another firm, which is clearly not strictly true. In the monopsonistic competition model of Bhaskar and To (1999), for example, the labor force participation rate increases with the wage, so the elasticity of recruitment is larger in magnitude than the elasticity of separations. Manning (2003, 96-105) discusses extensions of the search model that allow the impact of allowing the recruitment of nonemployed and separations to nonemployment to be sensitive to the wage as well. Unfortunately, the more sophisticated models he suggests require much more detailed data than are available to us.

Nevertheless, the Burdett-Mortensen-Manning framework does provide the insight that there is a link between the recruitment and the separation elasticities since a substantial portion of recruits does come from other employment. Furthermore, there is intuitive appeal in the idea that recruiting is approximately as responsive to changes in the wage as retention is.

Still, our results should be thought of as an approximation. Unfortunately, there is little empirical literature to guide us on the relative magnitudes. Perhaps the most relevant evidence comes from two studies based on the Employment Opportunity Pilot Project (EEOP), both discussed in Card and Krueger (1995, 375-76). Campbell (1993) estimates the elasticity of quits with respect to the wage to be about -1 . Holzer, Katz, and Krueger (1991) estimate the elasticity of job applications with respect to the wage for EEOP employers. Depending on their specification and the instruments used, they obtain estimates ranging from 0.5 to 4.1 . If one keeps in mind that job applications are not quite recruits and that the two studies are in other ways not exactly comparable, the evidence at least permits the possibility that the quit elasticity is equal to the recruit elasticity. Neither of these studies provides evidence on male/female differences in elasticities. 
Table 1 Company Characteristics: Retail Operations Selected Years (as of December 31)

\begin{tabular}{lrrrr}
\hline & 1977 & 1980 & 1982 & 1985 \\
\hline Number of stores & 59 & 61 & 58 & 54 \\
Number of retail employees & 1,522 & 1,968 & 1,820 & 1,533 \\
Percentage of employees who are female & 37.5 & 41.2 & 40.8 & 41.8 \\
Percentage of employees who are part-time & 42.1 & 55.1 & 56.9 & 62.6 \\
Average age & 32.5 & 32.2 & 33.4 & 34.9 \\
Average seniority & 6.0 & 5.8 & 7.1 & 8.9 \\
\hline
\end{tabular}

\section{The Firm}

The data we analyze come from a regional grocery retailer in the southwestern United States. We have year-end employment and wage data for the retail employees of the firm between 1976 and 1986. (By retail employees, we mean those who worked in the retail operations of the grocery stores themselves. Accountants, company officers, truck drivers, and the like are not included in our analysis.)

Table 1 summarizes a few of the characteristics of the firm during the time period that we analyze. The firm operated between 54 and 61 stores and had between about 1,500 and 2,000 retail employees. The number of stores and employees fluctuated somewhat, increasing early and then declining. During this period the firm opened several new stores and closed several old ones. ${ }^{4}$ Many of the company's retail employees worked parttime, with the prevalence of part-time work increasing noticeably over the period of our analysis. About $40 \%$ of employees were female, and this fraction remained fairly constant.

Figure 1 presents a simple organizational chart for employees of the company's retail operations. Each store had up to three salaried "management" positions: the store manager, the assistant manager, and the relief manager. Other workers were paid on an hourly basis. The largest group of these workers held the title of food clerk. Food clerk assignments included stocking shelves and operating cash registers. Produce clerks had the same pay scale as food clerks but worked in the produce department.

${ }^{4}$ The theory we present above invokes a steady state, which is clearly violated here: the firm opened and closed a number of stores, and employment grew and declined over different time periods. However, in our analysis, we use only variation in separations and wages across job titles to identify the elasticity of separations. Events such as a store closure will cause a large number of separations, but we do not expect these separations to be elastic with respect to the wage rate of particular job titles since each store has a similar distribution of workers across the different job titles. As we explain below, while the estimates we obtain tell us about the labor supply to the firm, the firm is constrained by union contracts and other institutions. So we do not expect the labor supply elasticities that we estimated to be useful in predicting the scale of the firm that we analyze. 


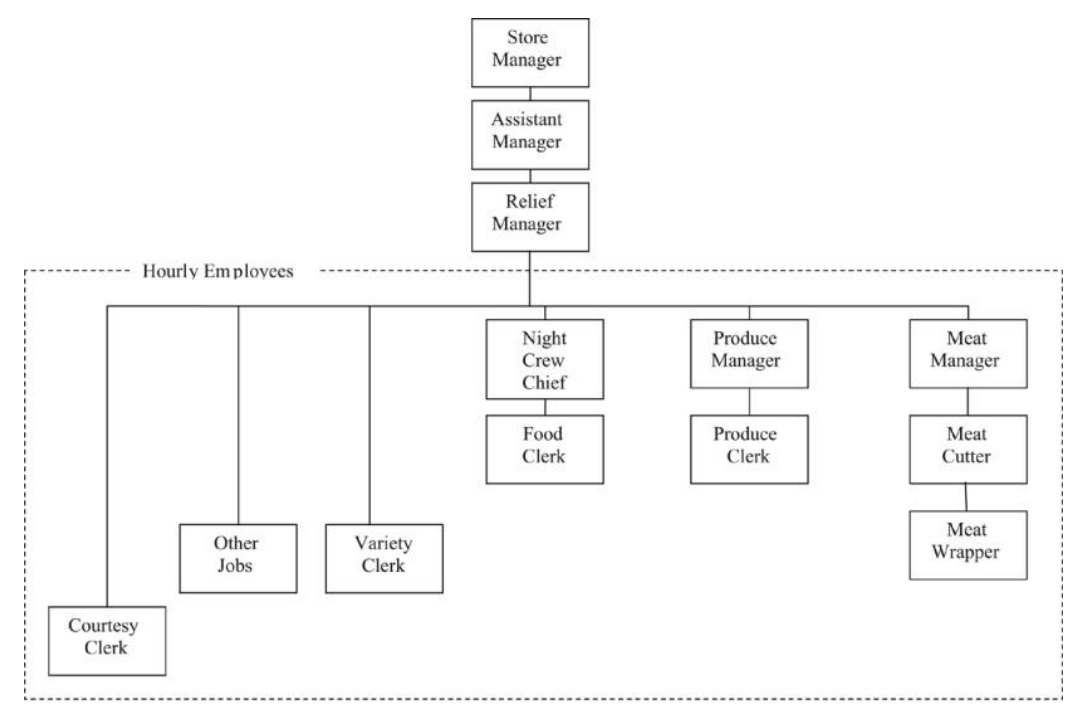

FIG. 1.-Organization of store-level employees

Variety clerks stocked shelves in the nonfoods department but earned less than food clerks. A few of the stores also had a bakery department, where bakery sales workers were employed. (There were apparently no actual bakers employed at these stores.) Courtesy clerks bagged and carried groceries for customers. The produce and meat departments had "managers" who received a pay premium but were part of their respective bargaining units. The night crew chief supervised stocking operations during the hours the stores were closed and also received premium wages.

All nonmanagement retail employees (including the department "managers") were covered by collective bargaining agreements. One contract covered the meat department employees, and another covered the other employees. We have examined the contract of one of the local unions, which was affiliated with the United Food and Commercial Workers Union. This was a multiemployer agreement that included several other large grocery chains in the region. Basically, the contract dictated pay, hours scheduling, benefits, and working conditions. The contract specified the wage levels for each of the job titles at the store, including seniority increments. Table 2 shows the contracted wage schedules for food clerks, variety clerks, and courtesy clerks as of December 28, 1980. Similar schedules applied to other dates during the period of our analysis. Other jobs, such as bakery sales worker, produce manager, and night crew chief, are not mentioned in the contract schedule, but wages for those jobs appear to be tied to the wage scale of food clerks.

Table 3 reports the average wage for workers within each job title as 
Table 2

Wage Schedules per Contract (as of December 28, 1980)

\begin{tabular}{lrlrlr}
\hline $\begin{array}{l}\text { Seniority } \\
\text { Level (Hours) }\end{array}$ & $\begin{array}{r}\text { Food } \\
\text { Clerk }\end{array}$ & \multicolumn{1}{c}{$\begin{array}{c}\text { Seniority } \\
\text { Level (Hours) }\end{array}$} & $\begin{array}{c}\text { Variety } \\
\text { Clerk }\end{array}$ & $\begin{array}{c}\text { Seniority } \\
\text { Level (Hours) }\end{array}$ & $\begin{array}{r}\text { Courtesy } \\
\text { Clerk* }\end{array}$ \\
\hline $0-1,040$ & $\$ 4.98$ & 0-1,040 & $\$ 4.814$ & $0-520$ & $\$ 3.35$ \\
$1,041-2,080$ & 5.81 & $1,041-2,080$ & 5.395 & $521-1,560$ & 3.45 \\
$2,081-3,120$ & 6.64 & Thereafter & 6.225 & Thereafter & 3.60 \\
Thereafter & 8.30 & Hired before 1/15/78 & 7.774 & &
\end{tabular}

$*$ The wages of courtesy clerks were tied to the federal minimum wage, which at the time was $\$ 3.35$. However, many courtesy clerks received a student subminimum wage of $\$ 2.85$.

of December 31, 1980 (i.e., at the beginning of 1981), along with the separation rate for that job title during the year, disaggregated by gender. The high level of gender segregation by job title is apparent in the table, with the produce department dominated by men, the variety department dominated by women, and jobs in the meat department perfectly segregated. Table 4 shows the job distribution of workers hired during the previous 6 months. This table strongly suggests that the segregation of workers is the result of job assignment at the time of hire. (Because of the snapshot nature of our data, we do not observe the job title assigned to a worker at the time of hire.) In their analysis of mobility within this firm, Ransom and Oaxaca (2005) found that there was little movement between job titles. Thus, job title at a given time is mostly determined by job title at the time of hire.

Job segregation at this employer tends to hurt female employees because women had limited access to the premium pay positions and because the female-dominated jobs tend to have lower wages and pay scales with fewer seniority increments. However, the primary focus of this article is not to explain gender pay differences at this firm but to use the differences in pay across job titles to help identify elasticities of labor supply. Below we will use the gender differences in the elasticities of labor supply to show that monopsony power could explain differences in pay in the grocery industry.

The logarithm of the separation rate is plotted against the logarithm of the average wage in figure 2 . The figure clearly demonstrates the strong negative correlation between the average wage of the job title and the separation rate for workers who began the year in that job. Essentially, this correlation is the empirical basis of our analysis that follows. A line fitted to these observations by a weighted regression yields a slope of about -1.2 , which is not too different from the estimates of the separation elasticity that we will report from our regression analysis for men. However, there are considerable differences across job titles in age and seniority, so not too much should be made of this visual.

Our approach implicitly treats the wages of workers as exogenous. On the one hand, wages for each job title are fixed by bargaining, and thus 


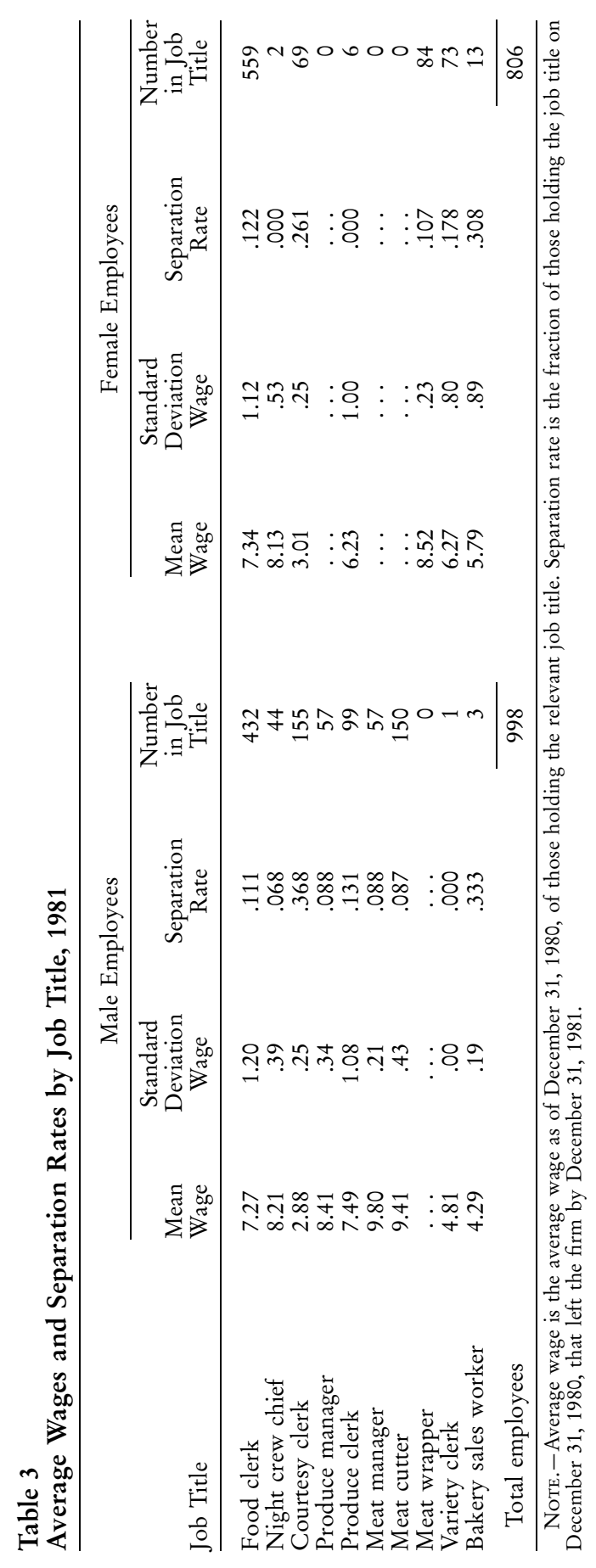


Table 4

Distribution of Recently Hired Workers by Job Title as of January 1, 1981

\begin{tabular}{lrr} 
Job Title & Male & Female \\
\hline Food clerk & 31 & 25 \\
Night crew chief & 1 & 0 \\
Courtesy clerk & 66 & 40 \\
Produce clerk & 3 & 0 \\
Meat cutter & 11 & 0 \\
Meat wrapper & 0 & 2 \\
Variety clerk & 0 & 5 \\
\cline { 2 - 3 } Total & 112 & 72 \\
\hline \multicolumn{2}{l}{ Note. - "Recently hired” means having less than 6 } \\
months' seniority. This distribution does not represent all \\
workers who were hired during the previous 6 month, \\
only those still employed on January 1, 1981.
\end{tabular}

the employer has no control over the wages. On the other hand, the employer assigns workers to jobs. If the employer considers anticipated turnover behavior in making that assignment, this could lead to bias in our estimated elasticities.

We also ignore working conditions that might vary between jobs. All employees worked at the same location. However, each job required particular skills, such as operating a cash register. Apparently employees were

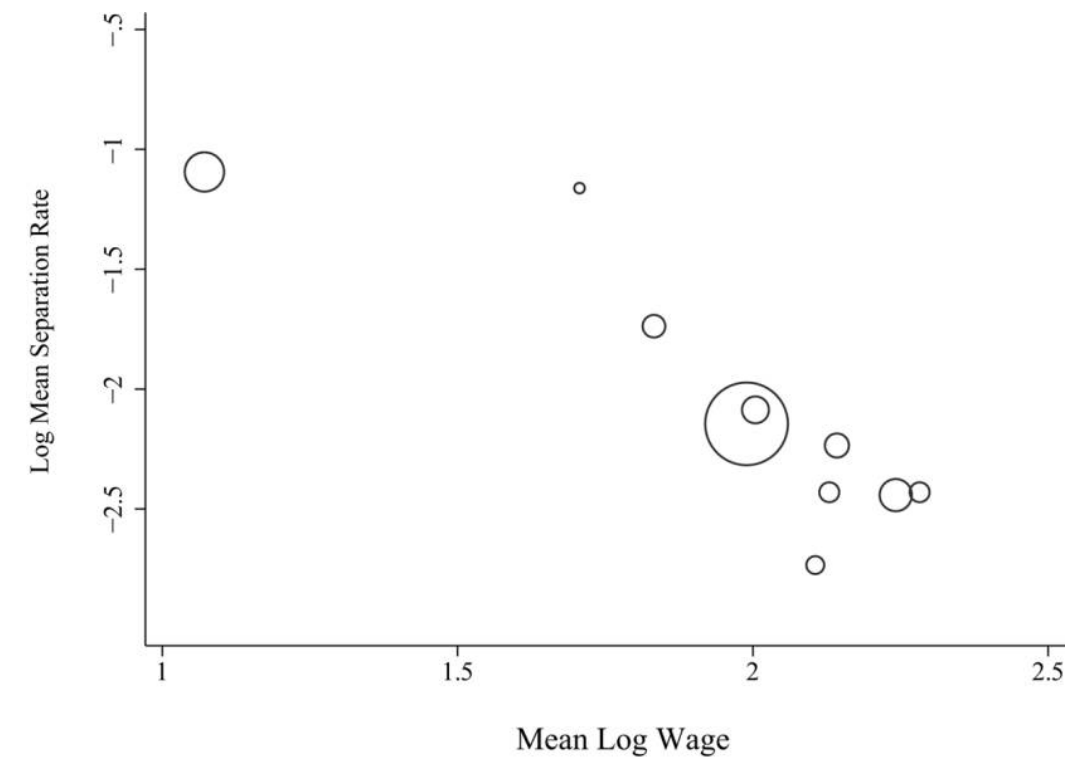

FIG. 2.-Separation rates versus wage rates by job title for 1981. The size of a circle represents the relative number of employees in that job title. 
mostly trained on the job, although provisions of the contract allowed for workers with previous experience as grocery store clerks to receive seniority credit for that experience. ${ }^{5}$ According to a supplementary survey of a small sample of employees, most employees were high school graduates with little or no college training. Analysis of that sample showed that formal educational credentials were unimportant in determining job placement and promotion for the positions that we consider here.

In the early 1980s, several women initiated a class-action lawsuit alleging that the employer had discriminated against women in job assignment (particularly in promotion to management) and in part-time/full-time work assignments. The court found the defendant guilty of discrimination in 1984, and the two parties reached a negotiated settlement in mid-1986 on terms of back pay and affirmative relief. However, the relief outlined in the settlement did not take place during the period of our analysis. Nevertheless, we might expect that the lawsuit itself may have had some impact on employment practices at the firm and perhaps on the way that women viewed their workplace and employer.

\section{Data}

The data we use come from year-end payroll files of the firm. These data include the wage and job title of the employee's current job, earnings for the past year, date of hire, and date of birth. Each year-end file contains a record of all employees who worked for the firm during the year, even though they may have terminated their employment before the end of the year. By matching consecutive years, we can identify those who stopped working for the firm during a given year. We have pooled workers for all years between 1977 and 1985. (We lose the first and last year because we cannot identify separation dates from the year-end files directly.) According to our definition, a separation occurred in year $t$ if someone was employed at the end of year $t-1$ and was no longer employed at the end of year $t$. We do not know the reason for the separation. We assume that virtually all of these are quits, but surely some would have been dismissals, retirements, or the like.

We analyze two time periods. First, we use the entire sample of 9 years. Next, we use a shorter sample of 6 years, from 1977 through 1982. We concentrate on the early years for two reasons: First, we have some concerns about how the lawsuit influenced employment practices. Second, there was a recession in the United States that began in the early 1980s. From 1977 to 1981 the U.S. unemployment rate averaged about $6.7 \%$, ranging from a low of $5.8 \%$ in 1979 to a high of $7.6 \%$ in 1981. In 1982, the last year of our prelawsuit sample, the unemployment rate rose to $9.7 \%$. A year later the unemployment rate remained high at $9.6 \%$. So for

\footnotetext{
${ }^{5}$ Specific skills may have been more important for meat department employees.
} 
Table 5

Summary Statistics for Grocery Store Data

\begin{tabular}{|c|c|c|c|c|}
\hline Variable & Mean & $\begin{array}{l}\text { Standard } \\
\text { Deviation }\end{array}$ & Minimum & Maximum \\
\hline & \multicolumn{4}{|c|}{ A. Full Sample: $1977-85(N=14,378)$} \\
\hline Separated & .16 & .37 & .00 & 1.00 \\
\hline Age & 32.75 & 12.61 & 16.04 & 74.63 \\
\hline Seniority & 6.02 & 5.81 & .02 & 3.83 \\
\hline Female & .44 & .50 & .00 & 1.00 \\
\hline Wage (nominal) & 7.34 & 2.56 & 1.96 & 12.47 \\
\hline Wage (1977 dollars) & 5.04 & 1.38 & 1.60 & 7.10 \\
\hline \multicolumn{5}{|c|}{$\begin{array}{l}\text { Fraction of sample from } \\
\text { each year: }\end{array}$} \\
\hline 1977 & .095 & & & \\
\hline 1978 & .095 & & & \\
\hline 1979 & .104 & & & \\
\hline 1980 & .120 & & & \\
\hline 1981 & .125 & & & \\
\hline 1982 & .126 & & & \\
\hline 1983 & .115 & & & \\
\hline 1984 & .111 & & & \\
\hline \multirow[t]{2}{*}{1985} & .108 & & & \\
\hline & \multicolumn{4}{|c|}{ B. Early Years: $1977-82(N=9,566)$} \\
\hline Separated & .16 & .36 & .00 & 1.00 \\
\hline Age & 32.17 & 12.78 & 16.03 & 71.63 \\
\hline Tenure & 5.38 & 5.58 & .03 & 34.54 \\
\hline Female & .43 & .50 & .00 & 1.00 \\
\hline Wage (nominal) & 6.38 & 2.05 & 1.96 & 10.82 \\
\hline Wage (1977 dollars) & 4.86 & 1.33 & 1.76 & 6.79 \\
\hline \multicolumn{5}{|c|}{$\begin{array}{l}\text { Fraction of sample from } \\
\text { each year: }\end{array}$} \\
\hline 1977 & .143 & & & \\
\hline 1978 & .143 & & & \\
\hline 1979 & .156 & & & \\
\hline 1980 & .180 & & & \\
\hline 1981 & .189 & & & \\
\hline 1982 & .189 & & & \\
\hline
\end{tabular}

all but one year of our subsample, the unemployment rate and economic conditions were relatively favorable compared with the period after the lawsuit. Consequently, the turnover we observe is more likely to consist of voluntary separations compared with the subsequent period. Table 5 presents summary statistics for the data we use in our analysis.

\section{Estimation of the Elasticity of Labor Supply to the Firm}

In order to infer the labor supply elasticities to the firm, we must first estimate the elasticity of the separation rate with respect to the wage. This can be calculated from a probit regression model of the form

$$
s_{i t}=\Phi\left(\alpha_{0}+\alpha_{1} \ln \left(w_{i t}\right)+X_{i t} B\right)=\Phi\left(I_{i t}\right),
$$

where $s_{i t}$ is the probability that an individual separates from the firm 
during the year, $\Phi\left(I_{i t}\right)$ is the normal cumulative distribution function evaluated at $I_{i t}, w_{i t}$ is the real wage at the start of the year, and $X$ represents a vector of other explanatory variables. We treat the wages of workers as fixed since they are exogenously determined by a set of contractual rules that are beyond the control of the employer and the worker. We estimate this equation separately for men and women employees.

We have estimated two versions of this model for each of the sample periods. Model I includes powers of age and a set of indicators for the year as the "other" explanatory variables. Age is included to capture differences in labor market experience, which might reflect differences in the skills of the workers. From the point of view of a search model, another reason to include age is that an employee's network of job market contacts might increase with age. Model II additionally includes seniority with the firm and its square. ${ }^{6}$

It is not clear that seniority ought to be included in a model of separations, but since some promotion and job assignment decisions may be based on seniority, we include them here. Seniority is highly positively correlated with the wage. If the decision to quit is actually based only on the current wage, inclusion of seniority is likely to confound the effect of the wage and lead to lower estimated elasticities. However, if seniority has an independent effect, say through some sort of matching on unobserved characteristics, then omitting seniority will lead (incorrectly) to larger estimated elasticities. We report results from both models but are inclined to favor those that include seniority. ${ }^{?}$

Table 6 reports the results of our estimation for the two different time periods that we analyze. The explanatory variables are all strongly related to the separation probabilities. The age variable enters as a cubic, but over the range from about 20 years old to 50 years old, the probability of separation decreases with age.

The seniority variable enters as a quadratic. The probability of separation decreases with seniority for the first 15 or 20 years depending on version and sample period; then it increases with seniority. ${ }^{8}$ The most

\footnotetext{
${ }^{6}$ We have also estimated models with more general specifications of seniority, including up to seven indicator variables for different seniority levels. In these models, the estimated elasticities decline somewhat, but the predicted effect on the male/female wage difference did not change.

${ }^{7}$ One simple reason that seniority might matter is that as an employee gains seniority, she gets closer to the next seniority step in the wage scale. Someone who is a few weeks away from a raise in pay may behave as if that expected wage, not the current wage, is the relevant one when considering the quit decision.

${ }^{8}$ The 95 th percentile of seniority in our sample is 18.7 years, so the marginal effect that we estimate is negative for virtually the entire sample of employees. When we estimate models with more general specifications of seniority, we observe a constantly declining effect of seniority on the separation probability, after controlling for age.
} 
Table 6

Probit Regressions: Estimates of Separations

\begin{tabular}{|c|c|c|c|c|}
\hline & \multicolumn{2}{|c|}{ Model I } & \multicolumn{2}{|c|}{ Model II } \\
\hline & Female & Male & Female & Male \\
\hline & \multicolumn{4}{|c|}{ A. Full Sample: All Years } \\
\hline Log wage & $\begin{array}{r}-.7499 \\
(.0909)\end{array}$ & $\begin{array}{r}-.8977 \\
(.0699)\end{array}$ & $\begin{array}{r}-.5480 \\
(.0961)\end{array}$ & $\begin{array}{c}-.7570 \\
(.0734)\end{array}$ \\
\hline Age & $\begin{array}{l}.2449 \\
(.0556)\end{array}$ & $\begin{array}{l}.0435 \\
(.0533)\end{array}$ & $\begin{array}{l}.2120 \\
(.0556)\end{array}$ & $\begin{array}{l}.0556 \\
(.0546)\end{array}$ \\
\hline $\mathrm{Age}^{2} / 10$ & $\begin{array}{r}-.0839 \\
(.0146)\end{array}$ & $\begin{array}{r}-.0229 \\
(.0144)\end{array}$ & $\begin{array}{c}-.0745 \\
(.0147)\end{array}$ & $\begin{array}{c}-.0238 \\
(.0148)\end{array}$ \\
\hline $\mathrm{Age}^{3} / 1,000$ & $\begin{array}{l}.0831 \\
(.0122)\end{array}$ & $\begin{array}{l}.0271 \\
(.0123)\end{array}$ & $\begin{array}{c}.0757 \\
(.0123)\end{array}$ & $\begin{array}{l}.0270 \\
(.0127)\end{array}$ \\
\hline Seniority & & & $\begin{array}{c}-.0682 \\
(.0123)\end{array}$ & $\begin{array}{c}-.059 \\
(.0109)\end{array}$ \\
\hline Seniority $^{2}$ & & & $\begin{array}{r}.00237 \\
(.0005)\end{array}$ & $\begin{array}{l}.0015 \\
(.0004)\end{array}$ \\
\hline Year dummies? & Yes & Yes & Yes & Yes \\
\hline Constant & $\begin{array}{r}-1.7345 \\
(.5906)\end{array}$ & $\begin{array}{c}.4686 \\
(.5388)\end{array}$ & $\begin{array}{r}-1.4800 \\
(.591)\end{array}$ & $\begin{array}{l}.2570 \\
(.557)\end{array}$ \\
\hline \multirow[t]{2}{*}{ Observations } & 6,320 & 8,058 & 6,320 & 8,058 \\
\hline & \multicolumn{4}{|c|}{ B. Early Sample: $1977-82$ Only } \\
\hline Log wage & $\begin{array}{r}-.6490 \\
(.1225)\end{array}$ & $\begin{array}{r}-.9572 \\
(.0855)\end{array}$ & $\begin{array}{c}-.452 \\
(.128)\end{array}$ & $\begin{array}{c}-.845 \\
(.0909)\end{array}$ \\
\hline Age & $\begin{array}{c}.2492 \\
(.0681)\end{array}$ & $\begin{array}{c}.0932 \\
(.0650)\end{array}$ & $\begin{array}{l}.220 \\
(.0684)\end{array}$ & $\begin{array}{l}.102 \\
(.0660)\end{array}$ \\
\hline $\mathrm{Age}^{2} / 10$ & $\begin{array}{r}-.0840 \\
(.0179)\end{array}$ & $\begin{array}{r}-.0352 \\
(.0177)\end{array}$ & $\begin{array}{r}-.0755 \\
(.0181)\end{array}$ & $\begin{array}{r}-.0360 \\
(.0181)\end{array}$ \\
\hline $\mathrm{Age}^{3} / 1,000$ & $\begin{array}{l}.0822 \\
(.0150)\end{array}$ & $\begin{array}{l}.0369 \\
(.0152)\end{array}$ & $\begin{array}{l}.0754 \\
(.0151)\end{array}$ & $\begin{array}{l}.0369 \\
(.0155)\end{array}$ \\
\hline Seniority & & & $\begin{array}{c}-.0742 \\
(.0148)\end{array}$ & $\begin{array}{c}-.0477 \\
(.0142)\end{array}$ \\
\hline Seniority $^{2}$ & & & $\begin{array}{l}.00293 \\
(.000596)\end{array}$ & $\begin{array}{l}.00141 \\
(.000571)\end{array}$ \\
\hline \multicolumn{5}{|l|}{ Year: } \\
\hline 1978 & $\begin{array}{c}.0789 \\
(.0950)\end{array}$ & $\begin{array}{l}.0959 \\
(.0780)\end{array}$ & $\begin{array}{l}.0628 \\
(.0953)\end{array}$ & $\begin{array}{l}-.108 \\
(.0782)\end{array}$ \\
\hline 1979 & $\begin{array}{r}-.1303 \\
(.0955)\end{array}$ & $\begin{array}{c}-.0936 \\
(.0798)\end{array}$ & $\begin{array}{c}-.130 \\
(.0960)\end{array}$ & $\begin{array}{c}-.203 \\
(.0792)\end{array}$ \\
\hline 1980 & $\begin{array}{r}-.0262 \\
(.0903)\end{array}$ & $\begin{array}{l}.0168 \\
(.0753)\end{array}$ & $\begin{array}{r}-.0267 \\
(.0906)\end{array}$ & $\begin{array}{c}-.0904 \\
(.0744)\end{array}$ \\
\hline 1981 & $\begin{array}{r}-.1155 \\
(.0901)\end{array}$ & $\begin{array}{c}-.0963 \\
(.0773)\end{array}$ & $\begin{array}{c}-.104 \\
(.0904)\end{array}$ & $\begin{array}{l}-.202 \\
(.0764)\end{array}$ \\
\hline 1982 & $\begin{array}{c}.0422 \\
(.0874)\end{array}$ & $\begin{array}{l}.1280 \\
(.0733)\end{array}$ & $\begin{array}{c}.0659 \\
(.0876)\end{array}$ & $\begin{array}{l}.0247 \\
(.0722)\end{array}$ \\
\hline Constant & $\begin{array}{r}-2.1213 \\
(.7085)\end{array}$ & $\begin{array}{r}-.2925 \\
(.6460)\end{array}$ & $\begin{array}{r}-1.949 \\
(.711)\end{array}$ & $\begin{array}{c}-.371 \\
(.658)\end{array}$ \\
\hline Observations & 4,143 & 5,408 & 4,143 & 5,408 \\
\hline
\end{tabular}

Note. - Standard errors are in parentheses. 
Table 7 Estimates of Labor Supply Elasticity to the Firm

\begin{tabular}{lcc}
\hline Method & $\begin{array}{c}\text { Estimates from } \\
\text { All-Years } \\
\text { Sample }\end{array}$ & $\begin{array}{c}\text { Estimates from } \\
\text { Early-Years } \\
\text { Sample }\end{array}$ \\
\hline A. Model I (model without seniority variables): & & \\
Men & 2.845 & 3.015 \\
Women & 2.445 & 2.105 \\
Implied female/male wage ratio & .9592 & .9028 \\
ln $\left(w_{f}\right)-\ln \left(w_{m}\right)$ & -.0417 & -.1023 \\
B. Model II (model with seniority variables): & 2.413 & 2.669 \\
Men & 1.793 & 1.474 \\
Women & .908 & .819 \\
Implied female/male wage ratio & -.096 & -.200 \\
ln $\left(w_{f}\right)-\ln \left(w_{m}\right)$ & & \\
\hline
\end{tabular}

visible difference between the two different time periods is that the coefficient on the log of the wage drops for women whereas it increases slightly for men. This results in much different elasticity estimates for women using the two periods. We do not have a good explanation for this, although women's expectations of employment conditions at the firm may have changed as a result of the lawsuit.

The separation elasticities can be calculated from the estimates of equation (4) in the following way:

$$
\varepsilon_{s w}=\frac{w}{s} \frac{\partial s}{\partial w}=\left(\frac{w}{s}\right)\left(\frac{\alpha_{1}}{w}\right) \varphi(I)=\alpha_{1}\left[\frac{\varphi(I)}{\Phi(I)}\right],
$$

where $I$ is the value of the index function that is estimated in the probit regression. In our specification of the separation rate function, the separation rate elasticity is proportional to the hazard rate (inverse Mills ratio).

In the context of our version of the Burdett-Mortensen-Manning model, the elasticity of labor supply to the firm is simply twice the negative of the separation elasticity, as derived in equation (3). However, because of the nonlinearity of the probit regression model, there is some ambiguity as to how to calculate "the" elasticity of labor supply to the firm. We adopt two approaches that are often used to evaluate the results of probit regressions. In the first, we evaluate the elasticity at the sample mean of the explanatory variables. That is, we evaluate the index function, $I$, using for the explanatory variables their overall sample means. The second method evaluates the elasticity for each individual in the sample and then averages those individual estimates for men and women. Both methods yield almost identical results for estimated elasticities, so we report only results of the first approach. Table 7 reports the estimated elasticities.

The monopsony model of wage discrimination provides predictions of male/female wage differences under the assumption that the firm is oth- 
erwise unconstrained. If we express the wage bill for the $j$ th group of workers as $N_{j} W\left(N_{j}\right)$, the marginal cost of hiring a worker of type $j$ is

$$
\operatorname{MLC}_{j}=w_{j}\left(1+\frac{1}{\varepsilon_{N w}^{j}}\right) .
$$

The employer maximizes profits by setting $\mathrm{MLC}_{f}$ equal to $\mathrm{MLC}_{m}$, so

$$
w_{f}\left(1+\frac{1}{\varepsilon_{N w}^{f}}\right)=w_{m}\left(1+\frac{1}{\varepsilon_{N w}^{m}}\right),
$$

and therefore the ratio of female to male wages is

$$
\frac{w_{f}}{w_{m}}=\frac{1+1 / \varepsilon_{N w}^{m}}{1+1 / \varepsilon_{N w}^{f}} .
$$

The logarithm of this ratio corresponds to the estimated log wage gap of $\ln \left(w_{f}\right)-\ln \left(w_{m}\right)$. The wage ratio and the log wage gap are also reported in table 7.9 Our estimates suggest that a wage difference of between $9 \%$ and $20 \%$ would arise if an employer in this market were able to take full monopsonistic advantage of the differences in labor supply elasticities between men and women.

Including seniority in the regression model reduces the estimated elasticity somewhat for men, but even more so for women, so that the predicted wage gap is approximately double for model II estimates.

The usual measure of monopsony power is called Pigou's exploitation index. It is defined as

$$
E=\frac{\mathrm{MRP}_{L}-w}{w}=\frac{1}{\varepsilon_{N w}},
$$

where $\mathrm{MRP}_{L}$ is the marginal revenue product of labor, and $E$ measures the percentage deviation of the market value of the worker's output from his or her wage. (This corresponds directly to the Lerner index used to measure monopoly power.) As shown by Boal and Ransom (1997) and others, this is just the inverse of the labor supply elasticity to the firm if the employer sets wages to maximize profits. Our estimates indicate that

${ }^{9}$ We note in passing that the log wage gap is approximately the difference between the exploitation indexes. From (7) above,

$$
\begin{aligned}
\ln \left(w_{f}\right)-\ln \left(w_{m}\right) & =\ln \left(1+1 / \varepsilon_{N w}^{m}\right)-\ln \left(1+1 / \varepsilon_{N w}^{f}\right) \\
& \approx 1 / \varepsilon_{N w}^{m}-1 / \varepsilon_{N w}^{f}=E_{m}-E_{f}
\end{aligned}
$$

if the exploitation is small (or the elasticity of labor supply to the firm is large). This approximation is not very accurate for our particular example, however, as our estimated elasticities are quite small. 
this firm has substantial potential market power: values of $E$ are as high as 0.4 for men and almost 0.6 for women.

\section{Can Monopsony Explain the Gender Wage Gap?}

We do not interpret our estimates to imply that the wages we observe at this firm would increase by $40 \%-60 \%$ if market frictions suddenly disappeared. This firm is obviously constrained in wage setting: its wagemaking power is tempered by the bargaining power of its workers and their unions and other institutions, such as minimum wage laws. In fact, in a sense the firm has little ability to set wages since wages for each job title are fixed by contract. We explicitly note this in our estimation procedure, which treats these wages as exogenously determined. The firm faces an upward-sloping labor supply curve-it has market power due to market frictions-but it is unable to take full advantage of it because of the institutions and environment in which it operates.

On the one hand, we really have not developed a model that allows us to point to monopsonistic discrimination as a source of gender differences in pay at this firm since we have not explained how women and men are assigned to jobs. If all jobs are filled, then it does not matter to the employer whether a particular job is filled by a woman or a manthe total wage bill will be the same. Of course, this is a very simplistic notion of the firm's employment decision making.

On the other hand, the firm likely has some scope to exert its power. In fact, women at this firm do receive lower wages than men with similar age and seniority. Ransom and Oaxaca (2005) show that this is due to the assignment of women to lower-paying jobs in the firm than similarly qualified men. ${ }^{10}$ Could this be due to the exercise of monopsony power? It is beyond the scope of this article to develop a model of job segregation based on monopsony power, but it is not hard to think of a model that is true to the spirit of monopsony that might work. Consider a firm in which there are turnover costs. The firm could reduce turnover by placing men in the high-wage jobs and women in the low-wage jobs since the elasticity of the quit rate with respect to the wage is higher for men. This would lead to lower turnover without increasing the wage bill.

We can think of this firm as a typical firm in this labor market. Given the presumed independence of firm labor supply and labor demand, our estimated labor supply elasticity should reflect what the firm would face even in the absence of labor market institutions such as unions. Thus, other firms that operate in the same labor market face the same labor supply curve. So we expect that other grocery stores (and perhaps em-

\footnotetext{
${ }^{10}$ They estimate that women were underpaid in 1982 by about $8 \%$ compared
} to similar men. 
Table 8

Estimated Gender Gap for Hourly Grocery Store Employees in the Current Population Survey Merged Outgoing Rotation Group Files (1979-82)

\begin{tabular}{lcc}
\hline Variable & $\begin{array}{c}\text { All United } \\
\text { States }\end{array}$ & $\begin{array}{c}\text { Southwest } \\
\text { Only }\end{array}$ \\
\hline Female & -.238 & -.195 \\
& $(.00598)$ & $(.0167)$ \\
Age & .123 & .154 \\
& $(.00468)$ & $(.0144)$ \\
Age ${ }^{2}$ & -.229 & -.296 \\
& $(.0124)$ & $(.0391)$ \\
Age $^{3}$ & .0125 & .0169 \\
& $(.00101)$ & $(.00329)$ \\
Education: & .119 & .136 \\
12 years & $(.00761)$ & $(.0239)$ \\
& .131 & .0943 \\
$13-15$ years & $(.00871)$ & $(.0242)$ \\
& .138 & .145 \\
16 years & $(.0176)$ & $(.0409)$ \\
$>16$ years & .0760 & .128 \\
& $(.0382)$ & $(.0784)$ \\
Year: & .0656 & .0419 \\
1980 & $(.00813)$ & $(.0225)$ \\
& .122 & .103 \\
1981 & $(.00822)$ & $(.0229)$ \\
& .169 & .189 \\
1982 & $(.00863)$ & $(.0242)$ \\
Constant & 4.336 & 4.076 \\
& $(.0498)$ & $(.153)$ \\
Observations & 14,808 & 1,945 \\
$R^{2}$ & .324 & .363 \\
\hline NotE.-Dependent variable is log wage. Robust standard er- \\
rors are in parentheses. & & \\
& &
\end{tabular}

ployers in other industries that tap the same market) have similar levels of market power.

To examine this question, we estimate gender wage differences among a broad sample of workers in grocery stores, using data from the Current Population Survey. We combine samples from the Merged Outgoing Rotation Groups from 1979 through 1982 and select individuals who work in the retail grocery industry and are paid on an hourly basis. Table 8 reports our results. From a national sample of slightly fewer than 15,000 workers, we estimate a disadvantage in pay for women of about $24 \%$. If we restrict our analysis to only those workers who lived in the southwest region (California, Arizona, Nevada, and Utah), the estimate is about $20 \%$ - exactly equal to the largest of our predicted wage gaps.

We think of our estimate of the exploitation index as a measure of potential market power of firms. This power to set wages is surely tem- 
pered by legal and institutional factors. For example, in this industry in this period of time, unionization is fairly common. Also, minimum wage laws probably have some impact on wage setting for this market. A comparison of the estimated gender wage gap for our firm with both the estimated potential gap and the estimated gap in the broader regional

labor market offers some sense of the limited ability of the firm to exercise its potential monopsony power.

We estimated the firm-specific gender wage gap over the same time period and with the same specification that was used for the broader labor market. In an alternative specification, we added tenure and tenure squared. We find that the gender wage gap for the firm ranged from $9 \%$ to $11 \%$, which is half of both the estimated potential gap and the estimated market gap. Consequently, to the extent that the institutional and legal constraints on firms' exercise of potential monopsony power are approximately the same for men and women in this industry, the predicted gender wage gap may be a good approximation of how even partial exercise of monopsony power contributes to gender wage differentials. The consistency of the predicted gender wage gap from the monopsony model with independent estimates of the gender wage gap supports the idea that monopsonistic discrimination may be one reason for the wage differences between men and women in this industry.

It is useful to place our analysis of a single firm in the broader context of the U.S. labor market. Generally, the female labor supply elasticity to the U.S. labor market exceeds the male elasticity of labor supply, as estimated in Triest (1990) and Blau and Kahn (2007). This is the opposite of what we find at the firm level because female labor supply to the labor market incorporates the labor force participation decision. Nevertheless, Blau and Kahn document a marked reduction in the female market labor supply elasticity so that it is fairly close to that of the males. In addition, there has been a documented convergence of the human capital of men and women. To the extent that the convergence of labor supply elasticities has also occurred at the firm level, though in reverse order, this convergence coupled with convergence in human capital could account for the documented narrowing of the gender wage gap.

\section{Discussion}

While our objective here has been to estimate an elasticity of labor supply to the firm, to do that we have in fact estimated the elasticity of the quit rate with respect to the wage. There is a substantial empirical literature on quit rates, with early influential papers by Parsons (1972) and Pencavel (1972), for example. More specifically, other papers have also examined differences in quit rates between men and women, such as Viscusi (1980), Blau and Kahn (1981), or Meitzen (1986). However, much 
of the literature is not concerned with how the quit rate responds to wages, and in those papers in which an elasticity-like coefficient is estimated, it is difficult to compare those rates directly with the ones that we have estimated here. The previous work that is most directly comparable to ours is Hirsch, Schank, and Schnabel (2010, in this issue). In their analysis of German data, they too find that labor supply elasticities to the firm are smaller for women than for men. Barth and Dale-Olsen (2009) also find that the elasticity of turnover with respect to the wage is greater for men than for women in a sample of Norwegian workers.

In the present study, we have taken a very static, "Robinsonian," approach to the interpretation of the elasticity of labor supply to the firm, which requires some formal departures from the search model that we used to motivate the analysis. For example, in the Burdett-MortensenManning model, each firm offers a single wage, whereas our objective is to examine within-firm wage differences. In the Burdett-MortensenManning model, productivity is determined by the firm (or perhaps the job), whereas our regression models, at least in spirit, assume that there are productivity differences across individuals.

Our approach is reduced form in nature. Others have applied more structural models. For example, Bowlus (1997) estimates the "primitive" parameters of a generalization of the Burdett-Mortensen model using data from the National Longitudinal Survey of Youth. She argues that gender differences in the parameters of the search model can explain a substantial part of the observed difference in wages. ${ }^{11}$ It is interesting to note that in the context of her model, there is no discrimination by employers, even though elasticities of labor supply differ by sex: each employer offers the same wage to all workers, but the equilibrium wage distribution of women has a lower expected value. ${ }^{12}$ In the spirit of Bowlus's approach, wage differences at our firm could arise because women "stick" in low-wage jobs, whereas men are more likely to move on to higher-paying jobs, even without any effort by the employer to take advantage of its monopsony position. (Our approach, however, stresses conscious wage discrimination by the employer.)

We have not provided an explanation for why the elasticity of labor supply of women is less than that of men. Our discussion to this point has treated these differences as if they are not based on employer prejudice. However, Black (1995) provides an interesting result in his analysis of discrimination in a search model. If some employers refuse to hire women,

${ }^{11}$ For technical reasons, Bowlus assumes that men and women do not work for the same employer. That is, employers hire either all men or all women.

${ }^{12}$ Mortensen (2003) is an example of an empirical study that examines the monopsony issue within the context of a structural equilibrium search model. However, his paper does not address male/female differences in wages. 
this will reduce the flow of job offers to women. In our model, that could lead to a lower elasticity of labor supply to the firm, even if this firm does not have a prejudice against women. In that sense, prejudice of some employers could increase the monopsony power of all employers.

\section{Summary and Conclusions}

In this article, we have estimated the sensitivity of separations to the wage rates offered to different employees within a regional grocery chain. We argue that this provides an estimate of the labor supply elasticity for this firm. Our estimates imply an elasticity of about 2.4-3 for men and about 1.5-2.5 for women, depending on the specification. This indicates that firms have significant potential monopsony power, although this monopsony power would likely be tempered by labor market institutions, such as unions, or by labor market regulations. The difference in the labor supply elasticities of men and women suggests a role for monopsony power in explaining male/female differences in pay.

\section{References}

Barth, Erling, and Harald Dale-Olsen. 2009. Monopsonistic discrimination and the gender wage gap. Discussion Paper no. 3930, Institute for the Study of Labor (IZA), Bonn, Germany.

Becker, Gary S. 1971. The economics of discrimination. 2nd ed. Chicago: University of Chicago Press.

Bhaskar, V., Alan Manning, and Ted To. 2002. Oligopoly and monopsonistic competition in labor markets. Journal of Economic Perspectives 16, no. 2:155-74.

Bhaskar, V., and Ted To. 1999. Minimum wages for Ronald McDonald monopsonies: A theory of monopsonistic competition. Economic Journal 109, no. 455:190-203.

Black, Dan. 1995. Discrimination in an equilibrium search model. Journal of Labor Economics 13, no. 2:309-33.

Blau, Francine D., and Lawrence M. Kahn. 1981. Race and sex differences in quits by young workers. Industrial and Labor Relations Review 34, no. 4:563-77.

- 2007. Changes in the labor supply behavior of married women: 1980-2000. Journal of Labor Economics 25, no. 3:393-438.

Boal, William M., and Michael R Ransom. 1997. Monopsony in the labor market. Journal of Economic Literature 35, no. 1:86-112.

Bontemps, Christian, Jean-Marc Robin, and Gerard J. Van den Berg. 1999. An empirical equilibrium job search model with search on the job and heterogeneous workers and firms. International Economic Review 40, no. 4:1043-74. 
Bowlus, Audra. 1997. A search interpretation of male-female wage differential. Journal of Labor Economics 15, no. 4:625-57.

Burdett, Kenneth, and Dale T. Mortensen. 1998. Wage differentials, employer size, and unemployment. International Economic Review 39, no. 2:257-73.

Campbell, Carl M., III. 1993. Do firms pay efficiency wages? Evidence with data at the firm level. Journal of Labor Economics 11, no. 3:422-70.

Card, David, and Alan B. Krueger. 1995. Myth and measurement: The new economics of the minimum wage. Princeton, NJ: Princeton University Press.

Hirsch, Boris, Thorsten Schank, and Claus Schnabel. 2010. Gender differences in labor supply to monopsonistic firms: An empirical analysis using linked employer-employee data from Germany. Journal of Labor Economics 28, no. 2:291-330.

Holzer, Harry J., Lawrence F. Katz, and Alan B. Krueger. 1991. Job queues and wages. Quarterly Journal of Economics 106, no. 3:739-68.

Kuhn, Peter. 2004. Is monopsony the right way to model labor markets? A review of Alan Manning's Monopsony in motion. International Journal of the Economics of Business 11, no. 3:369-78.

Madden, Janice Fanning. 1973. The economics of sex discrimination. Lexington, MA: Lexington.

Manning, Alan. 2003. Monopsony in motion. Princeton, NJ: Princeton University Press.

Meitzen, Mark E. 1986. Differences in male and female job-quitting behavior. Journal of Labor Economics 4, no. 4:151-67.

Mortensen, Dale T. 2003. How monopsonistic is the (Danish) labor market? In Knowledge, information and expectations in modern macroeconomics, ed. Philippe Aghion, Roman Frydman, Joseph Stiglitz, and Michael Woodford. Princeton, NJ: Princeton University Press.

Parsons, Donald O. 1972. Specific human capital: An application to quit rates and layoff rates. Journal of Political Economy 80, no. 6:1120-43.

Pencavel, John. 1972. Wages, specific training, and labor turnover in U.S. manufacturing industries. International Economic Review 13, no. 1: 53-64.

Ransom, Michael R, and Ronald L. Oaxaca. 2005. Intrafirm mobility and sex differences in pay. Industrial and Labor Relations Review 58, no. 2:219-37.

Robinson, Joan. 1969. The economics of imperfect competition. 2nd ed. London: Macmillan.

Samuelson, Paul A. 1958. Economics: An introductory analysis. 4th ed. New York: McGraw-Hill.

Schlicht, Ekkehart. 1982. A Robinsonian approach to discrimination. Journal of Institutional and Theoretical Economics 138, no.1:64-83. 
Triest, Robert K. 1990. The effect of income taxation on labor supply in the United States. Journal of Human Resources 25, no. 3:491-516.

Viscusi, W. Kip. 1980. Sex differences in worker quitting. Review of Economics and Statistics 62, no. 3:388-98. 